\title{
RARE MALPOSITION OF CENTRAL VENOUS CATHETER
}

\section{AUTORI}

KORESPONDENT

Nebojša Videnović

Institut za anesteziologiju i intenzivno

lečenje Medicinskog fakulteta

Univerziteta u Prištini

Kosovska Mitrovica, Srbija

vidneb@yahoo.com

Videnovic Nebojsa ${ }^{1}$, Stojicevic Bojan ${ }^{2}$, Zdravkovic Ranko ${ }^{3}$, Mladenovic Jovan ${ }^{4}$

${ }^{1}$ Department of Anesthesiology and Intensive Care, Medical Faculty University of Pristina, Kosovska Mitrovica, Serbia

${ }^{2}$ General Hospital of Kosovska Mitrovica, Serbia

${ }^{3}$ Department of Anesthesiology, Clinic for Cardiovascular Surgery, Institute of Cardiovascular Diseases of Vojvodina, Sremska Kamenica, Serbia

${ }^{4}$ Department of Surgery, Medical Faculty University of Pristina, Kosovska Mitrovica, Serbia

\section{SUMARY}

Introduction: Although placement of the central venous catheter is a routine procedure carried out by anesthesiologists, it carries a certain risk of complications. One of the complications is malposition, or inadequate catheter position.

Case report: We present a case of the patient who was admitted to an intensive care unit due to head injury and blood vomiting. The central venous catheter was inserted through the right internal jugular vein. Due to haemodynamic instability and the need for fluid and blood infusion, a chest $\mathrm{x}$-ray examination was not immediately performed to evaluate the position of the catheter. After the patient was stabilized, the test was performed and revealed that the tip of the catheter was not located in the superior vena cava but in the right subclavian vein.

Conclusion: This case has shown that the misplacement of the central venous catheter tip is not unusual. Once in the venous system, even when it is not located in the superior vena cava, it can be used for initial fluid replacement and drug administration, and after the patient is stabilized, the repositioning or placement of a new catheter should be considered.

Key words: internal jugular vein, subclavian vein, malposition, venous catheter

\section{SRPSKI}

\section{RETKA MALPOZICIJA CENTRALNOG VENSKOG KATETERA}

Videnović Nebojša ${ }^{1}$, Stojićević Bojan ${ }^{2}$, Zdravković Ranko ${ }^{3}$, Mladenović Jovan ${ }^{4}$

${ }^{1}$ Institut za anesteziologiju i intenzivno lečenje Medicinskog fakulteta Univerziteta u Prištini, Kosovska Mitrovica, Srbija

${ }^{2}$ Opšta bolnica u Kosovskoj Mitrovici, Srbija

${ }^{3}$ Institut za anesteziologiju, Klinika za kardiovaskularnu hirurgiju, Institut za kardiovaskularne bolesti Vojvodine, Sremska Kamenica, Srbija

${ }^{4}$ Institut za hirurgiju Medicinskog fakulteta Univerziteta u Prištini, Kosovska Mitrovica, Srbija

\section{SAŽETAK}

Uvod: lako je plasiranje centralnog venskog katetera rutinska procedura koju izvode anesteziolozi, ono nosi određeni rizik od komplikacija. Jedna od komplikacija je malpozicija, odnosno neadekvatna pozicija katetera.

Prikaz slučaja: Predstavljamo slučaj pacijentkinje koja je primljena u jedinicu intenzivne nege zbog povrede glave i povraćanja sveže krvi. Plasiran joj je centralni venski kateter kroz desnu unutrašnju jugularnu venu. Zbog hemodinamske nestabilnosti i potrebe za ordiniranjem tečnosti i krvi, nije odmah urađen RTG snimak grudnog koša radi procene položaja katetera. Nakon stabilizacije pacijentkinje, urađen je RTG snimak koji je pokazao da se vrh katetera ne nalazi u gornjoj šupljoj veni već u desnoj veni subklaviji.

Zaključak: Ovaj slučaj je pokazao da vrh centralnog venskog katetera ne završi uvek u gornjoj šupljoj veni. Kada se nalazi u venskom sistemu, čak i kada nije u gornjoj šupljoj veni, može u urgentnim situacijama poslužiti za inicijalnu nadoknadu tečnosti i aplikovanje lekova, a po stabilizaciji pacijenta treba razmotriti repoziciju ili plasiranje novog katetera.

Ključne reči: unutrašnja jugularna vena, vena subclavia, malprezentacija, venski kateter 


\section{INTRODUCTION}

Central venous catheter (CVC) placement is a procedure that is almost without exception used in the pre-operative treatment of critically ill and patients in intensive care units (ICU). CVC can be placed centrally or peripherally, and the preferred sites for insertion are internal jugular vein (IJV) and subclavian vein (SV). CVC is widely used in administration of fluids, blood products, parenteral nutrition or drugs; placement of temporary pacemakers etc. Arguably, the role of CVC in central venous pressure (CVP) measurement is irreplaceable.

Although relatively safe, numerous complications occurring during CVC placement as well as maintenance have been reported. Complications are estimated to occur in 2 $26 \%$ of cases. (1) Complications of insertion of CVCs include mechanical, infectious and thrombotic complications.(2) The most common complications are hematoma, infection, and pneumothorax. (3) Other complications are rare.

In order to reduce the incidence of complications, this procedure is usually carried out by well-trained physicians. However, complications are sometimes inevitable despite all precautionary measures. One of the complications not dependent on the performer's experience is malposition or inadequate CVC position.(4) Interestingly, although the use of ultrasound significantly increases the success rate of vein cannulation, it does not diminish the possibility of catheter tip malposition.(5)

We present a case report of a misplaced CVC from right internal jugular vein to right subclavian vein.

\section{CASE REPORT}

A 79-year-old patient was admitted to the ICU due to blood vomiting and head injury. On admission, she was conscious and hemodynamically stable, breathing spontaneously and sufficiently. Diagnostic (CT of endocranium, chest radiograph and ultrasound of the abdomen) and laboratory tests were carried out. After the initial treatment and assessment of the patient's condition, there was no need for CVC placement. Intravenous cannula $16 \mathrm{G}$ was inserted into peripheral vein. We placed chest electrodes for continuous monitoring of ECG, cuff for non-invasive blood pressure measurement (NIBP), pulse oximeter for measuring oxygen saturation, nasogastric tube and urinary catheter.

$\mathrm{CT}$ of endocranium showed haemorrhagic mass in the right nasal cavity and ethmoid sinus (Figure 1). The otorhinolaryngologist who performed anterior nasal packing was consulted. A few hours after the tamponade was done, the patient vomited blood, she was hemodynamically unstable and there was a drop in blood pressure. There was also a decrease in hemoglobin concentration. Due to the need for fluid and blood administration, as well as for hemodynamic status monitoring, CVC was placed.

Under sterile conditions (cap, mask and sterile gloves), the puncture site was disinfected with iodine solution and protected with sterile compress. We used Seldinger technique for internal jugular vein puncture (Figure 2 ). The vein was accessed on the first attempt. There was no resistance in advancement of the guidewire to the second marker (20 $\mathrm{cm})$. Resistance was encountered at the second marker, the guidewire was withdrawn $1-2 \mathrm{~cm}$ and rotated to the right. Further advancement of the guidewire went smoothly, as well as CVC placement. The triple lumen Brown catheter was placed. Dark venous blood was aspirated through all three lumens of the catheter. Due to the general condition of the patient and the need for fluid and blood administration, the radiological examination of the CVC position was not immediately done.

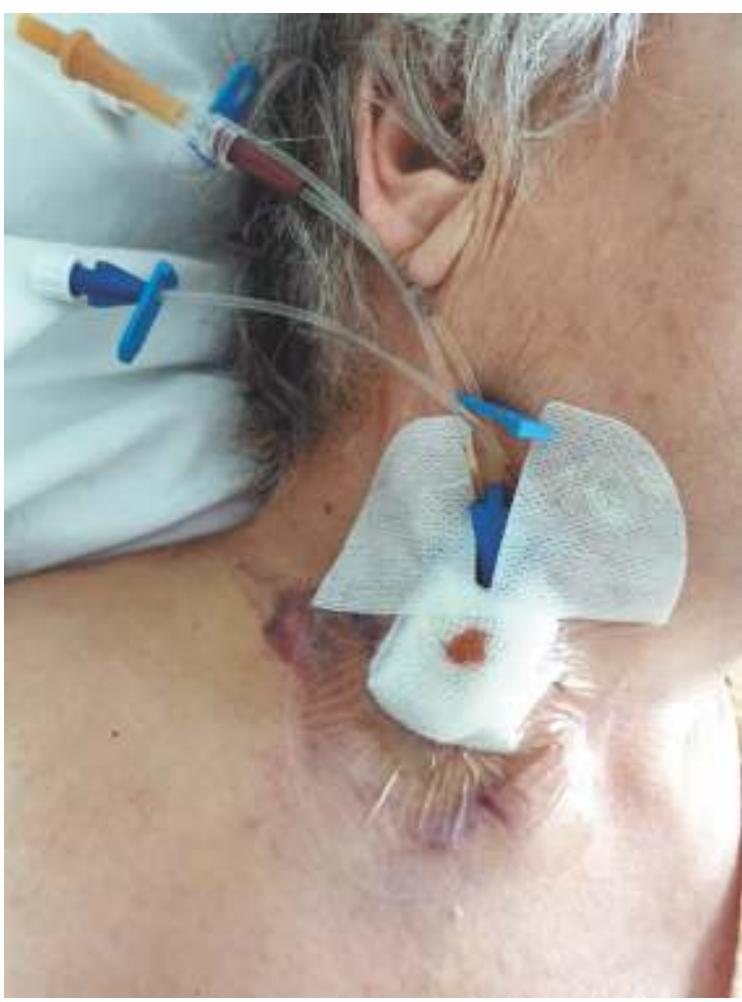

Figure 1.

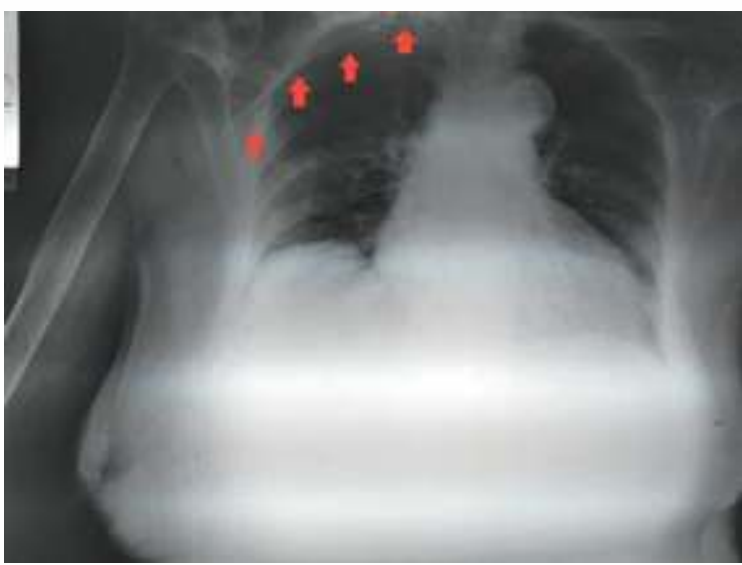

Figure 2.

After haemodynamic stabilization, a chest $x$-ray examination was performed showing that the CVC peak was not in the superior vein cava (SVC) but in the right SV (Figure 3 ). Considering that the patient's condition was improved and there was no need for vasoactive therapy, we felt that there was no need to place a new CVC. 


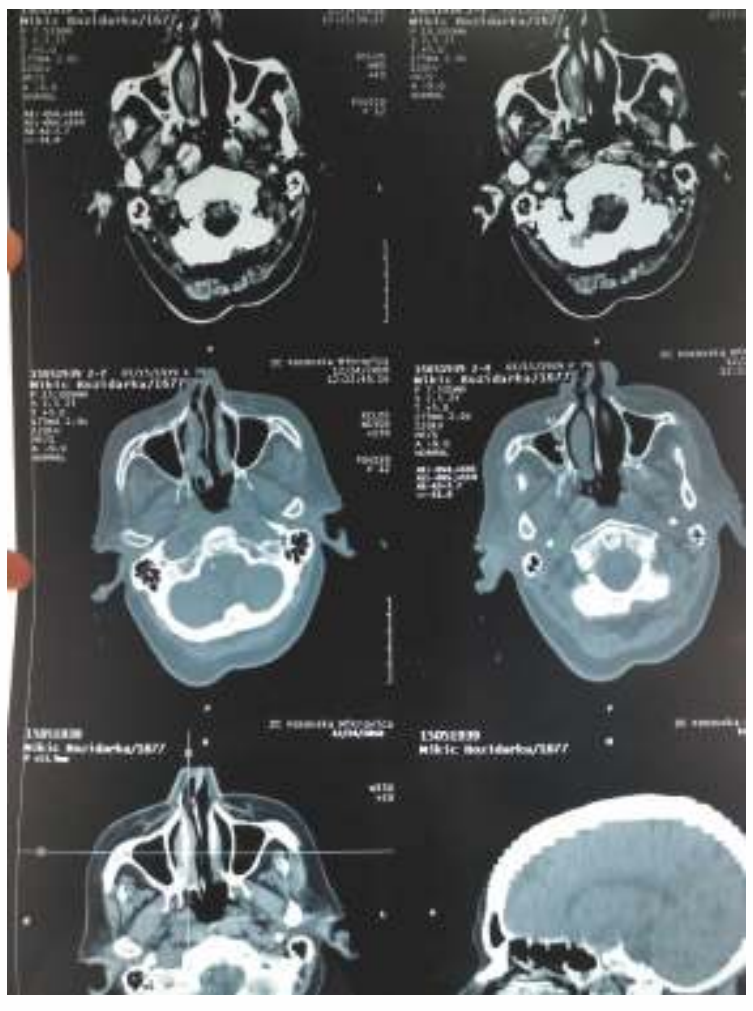

Figure 3.

After five days of treatment in the ICU, the patient was transferred to the department of surgery in a stable general condition.

\section{DISCUSSION}

For accurate CVP measurement, the tip of the central venous catheter (CVC) should lie within the SVC, above its junction with the right atrium. Malposition CVC refers to a catheter whose tip does not lie in the 'ideal' position. The incorrect positioning leads not only to inaccurate CVP values but can also lead, depending on localization, to erosion of the vein wall, vein perforation, local venous thrombosis, catheter dysfunction, etc.(6)

Right-sided subclavian access carries a higher risk of malposition (9.1\%), compared to IJV access (1.4\%).(7) The incidence of malposition depends on the site of insertion and the used material, the type of material used, but not on the experience of the physician who inserted the catheter4 and innate and acquired anomalies of the blood vessels. Some of the innate factors are: persistent left SVC, SVC variations, dextrocardia, varicella of the IVC, variations of the azygos venous system.(8) Acquired factors are much more common causes of malposition and can be of internal or external origin. Venous thrombosis or stenosis are the most com-mon internal causes. External causes are mainly tumor formations causing external pressure on the vein (lungs or breast tumors, lymphomas, thymo-mas, etc.) (9)

Internal jugular vein access has the advantage of direct access to the superior vena cava. Malposition can be of two types, intracaval and extracaval, according to the location of the catheter.(10) It is described in almost all possible anatomical locations: arterial system, mediastinum, pleura, pericardium, trachea, esophagus, subarachnoid space and other sites. $(11,12)$
It may occur during catheter placement or later as a result of spontaneous migration due to anatomical positioning or changes in pressure in the thoracic cavity. Therefore, routine chest $x$-ray examination is recommended for the evaluation of catheter position and recording of possible complications.(13) There are authors who do not recommend a routine radiographic testing due to the low incidence of malposition.(14)

We assume that the reason for malposition in our case was rotating the guidewire to the right when it met resistance at the second marker. At that point, the guidewire tip advancing through right brachiocephalic vein changed the direction and turned to the right subclavian vein. As venous blood was aspirated, we did not suspect the malposition. However, aspiration of blood after placement of the catheter does not guarantee correct catheter positioning. (13) Although the tip of the catheter was not in the SVC, it was still in the venous system, thus we used it to administer fluids and drugs and stabilize the patient.

\section{CONCLUSION}

Placement of CVC carries a certain risk of complications even with experienced physicians. Although not common, catheter tip malposition is a known complication. This case has shown that once in the venous system, even when it is not located in the superior vena cava, the catheter tip can be used for initial fluid replacement and drug administration, and after the patient is stabilized, the repositioning or placement of a new catheter should be considered.

\section{ACKNOWLEDGEMENTS}

The authors thank the collaboration of all elements of the Medical Faculty University of Pristina - Kosovska Mitrovica and General Hospital of Kosovska Mitrovica, Serbia.

\section{FUNDING}

This research received no specific grant from any funding agency in the public, commercial, or not-for-profit sectors.

\section{AVAILABILITY OF DATAAND MATERIALS}

The authors declare having followed the protocols in use at their working center regarding patients' data publication.

\section{CONFLICT OF INTEREST}

The authors declare to have no conflict of in-terest directly or indirectly related to the manu-script contents.

\section{ETHICALAPPROVAL}

The authors declare that the procedures were followed according to the regulations established by the Clinical Research and Ethics Committee and to the Helsinki Declaration of the World Medical Association. 


\section{LITERATURE}

1. Moeinipour AA, Amouzeshi A, Joudi M, Fathi M, Jahanbakhsh S, Hafez S, et al. A rare central venous catheter malposition: a case report. Anesthesiology and Pain Medicine. 2014;4(1):e16049. doi: 10.5812/aapm.16049.

2. Sakan S, Basić-Jukić N, Kes P, Stern-Padovan R, Perić M. Malposition of central venous dialysis catheter in the right internal mammary vein in uremic patient: case report. Acta Clinica Croatica. 2011;50(4):623-6. PMID: 22649898

3. McGee DC, Gould MK. Preventing complications of central venous catheterization. N Engl J Med. 2003; 348(12):1123-33. doi: 10.1056/NEJMra011883

4. Muhm M, Sunder-Plassmann G, Apsner R, Pernerstorfer T, Rajek A, Lassnigg A, et al. Malposition of central venous catheters. Incidence, management and preventive practices. Wien Klin Wochenschr. 1997;109:400-5. PMID: 9226858

5. Bertini P, Frediani M. Ultrasound guided supraclavicular central vein cannulation in adults: a technical report. J Vasc Access. 2013;14(1):89-93. doi: 10.5301/jva.5000088

6. Walshe C, Phelan D, Bourke J, Buggy D. Vascular erosion by central venous catheters used for total parenteral nutrition. Intensive Care Med. 2007;33(3):534-7. doi: 10.1007/s00134-006-0507-9

7. Pikwer A, Bååth L, Davidson B, Perstoft I, Akeson J. The incidence and risk of central venous catheter malpositioning: $\mathrm{A}$ prospective cohort study in 1619 patients. Anaesth Intensive Care. 2008;36:30-7. doi: 10.1177/0310057X0803600106

8. Davies M, Guest PJ. Developmental abnormalities of the great vessels of the thorax and their embryological basis. $\mathrm{Br} \mathrm{J}$ Radiol. 2003;76(907):491-502. doi: 10.1259/bjr/14043447

9. Granziera E, Scarpa M, Ciccarese A, Filip B, Cagol M, Manfredi V, et al. Totally implantable venous access devices: retrospective analysis of different insertion techniques and predictors of complications in 796 devices implanted in a single institution. BMC Surg. 2014;14:27.

10. Gibson F, Bodenham A. Misplaced central venous catheters: Applied anatomy and practical management. Br J Anaesth. 2013;110(3):333-46. doi: 10.1093/bja/aes497

11. Bodenham A. Reducing major procedural complications from central venous catheterisation. Anaesthesia. 2011;66:6-9. doi: $10.1111 / \mathrm{j} .1365-2044.2010 .06583 . x$

12. Cook TM. Litigation related to central venous access by anaesthetists: an analysis of claims against the NHS in England 1995-2009. Anaesthesia. 2011;66:56-7. doi:10.1111/j.1365-2044.2010.06569.x

13. Ghatak T, Azim A, Baronia AK, Muzaffar SN. Malposition of central venous catheter in a small tributary of left brachiocephalic vein. J Emerg Trauma Shock. 2011;4:523-525. doi: 10.4103/0974-2700.86653

14. Fragou M, Gravvanis A, Dimitriou V, Papalois A, Kouraklis G, Karabinis A, et al. Real-time ultrasound-guided subclavian vein cannulation versusthe landmark method in critical care patients: A prospective randomized study. Crit Care Med. 2011;39:1-6. doi: 10.1097/CCM.0b013e318218a1ae 